\title{
DEBS v. THE UNITED STATES-A JUDICIAL MILEPOST ON THE ROAD TO ABSOLUTISM *
}

\section{FORREST REVERE BLACK †}

The high-water mark of liberalism in freedom of speech cases was reached in Schenck $v$. United States, ${ }^{1}$ when Justice Holmes, speaking for a unanimous court, formulated the "clear and present danger" test as a canon of interpretation of the First Amendment of the federal Bill of Rights. The test as formulated by the Court was as follows: "The question in every case is whether the words used are used in such circumstances and are of such a nature as to create a clear and present danger that they will bring about the substantive evils that Congress has a right to prevent."

In order to appreciate the significance of the $D e b s$ decision ${ }^{2}$ it should be noted (I) that the Debs case was decided just one week after the Schenck ${ }^{3}$ case; (2) that Mr. Justice Holmes again spoke for a unanimous Court and (3) that the Court abandoned the liberal "clear and present danger" test of the Schenck case in order to "get its man". The liberality of the Schenck doctrine and the departure from it in the Debs case can only be comprehended by tracing historically the evolution of freedom of speech principles in Anglo-American law.

Liberty of opinion and the freedom to express that opinion in speech or press is the last and dearest right that has been wrested by the people from an unwilling church and state. The history of this struggle furnishes the focal point in the story of the development of popular government, and emphasizes in a peculiar way the importance of the adage, "eternal vigilançe is the price of liberty". The interest that the principle of freedom of speech defends is in a very real sense the most fundamental in the Bill of Rights. It is basic to the existence and perpetuity of popular government. No one has stated this idea so succinctly and eloquently as David Lloyd George: "In a free government, you must talk your way to good government, for there are

* This article is one of a series to be published in book form under the general caption "Judicial Mileposts on the Road to Absolutism". Other chapters have appeared as follows: Carroll v. United States (I929) 29 CoL. L. Rev. I069; Missouri v. Holland (I93I) 25 Ir工. L. Rev. gII ; The Selective Draft Cases (I93I) II B. U. L. REv. 37; Burdeau v. McDowell (I932) I2 B. U. L. REv. 32.

t A. B. (Ig16), University of Wisconsin; M. A. (I919), Columbia University; LL. B. (1920), Ohio State University; Ph. D. (I925), Robert Brookings Graduate School of Government; Instructor in Political Science, University of Minnesota, 1921-1922; Assistant Professor of Political Science, Washington University, 1922-1923, and Associate Professor 1923I924; Associate Professor of Political Science, University of Iowa, 1925-I927; Professor of Law, University of Kentucky since 1927; contributor to various law reviews.

$i_{249}$ U. S. $47,52,39$ Sup. Ct. 247, 249 (I9I9).

2 Debs v. United States, 249 U. S. 2 II, 39 Sup. Ct. 252 (I9I9). I0, I9I9.

${ }^{3}$ The Schenck case was decided on March 3, I9I9; the Debs case was decided on March 
so many to persuade. A program is successful when a truth becomes a tag -in the end we are governed by the winning tag. That is the result of talk. It is the only method ever known of running a free government. The men therefore, who despise talk, themselves talk nonsense, and mischievous nonsense at that". 4

In order to establish an historical setting for the Schenck and Debs cases we intend to trace briefly the main steps in the development of freedom of speech and press. There was a time in the early history of the English common law, concerning which Sir Mathew Hale said, "That almost every offense that was or seemed to be a breach of the faith or allegiance to the King, was by construction and consequence and interpretation raised into the offense of high treason." 5

The delegates who framed our Constitution knew all too well the tyrannical character of "constructive treason". They were familiar with the fact that violent factions had employed this vicious doctrine to wreak their alternate malignity on each other. They knew that English politics was invariably involved in treason prosecutions and that men were sent to the gallows for "imagining the King's death". Some of them perhaps had read of the case of one Walter Walker, who in the reign of Edward IV resided at "The Sign of the Crown". He was indicted for the treason of "compassing the death of the King" and was convicted and executed, because he told his little boy, that if he would be quiet, he would make him heir to the Crown. The plea that he referred to the Inn and not to the throne was made in vain. ${ }^{6}$ In the same reign, one Thomas Burdett owned a white buck which he kept in his park. Edward IV killed it while on a hunting expedition. Burdett was convicted of treason and executed merely because he said "he wished the buck, horns and all in the belly of him who counselled the King to do it". It so happened that the King acted on his own initiative and without counsel. ${ }^{7}$ Then there was the famous case of Colonel Algernon Sidney who committed to writing his ideas of the desirability of a different form of government. He was charged with treason and executed, although the papers were never published and were found concealed in a closet in his home when he was arrested. The decision was based on the theory that "to write is to commit an overt act". 8

To curb this peril to free institutions and forever to prevent the repetition of these injustices, the framers of the Constitution erected a parchment barrier in the form of three limitations on the governmental authorities in treason cases. First, the Constitution defines the crime; second, it fixes the

\footnotetext{
- Inaugural address as Rector of Edinburgh University, 1923.

32 HaLe, Pleas of the Crown (I847) \$\$ I, 80, 82.

- I HALE, op. cit. supra note 5, at II5.

TIbid.

${ }^{8}$ Foster, Crown Law (1767) 198.
} 
proof necessary for conviction; and third, the Congress is restrained, even in punishing the crime, from extending the consequences of guilt beyond the person of its author. Article 3, Section 3, Clause I provides, "Treason against the United States shall consist only in levying war against them, or in adhering to their enemies, giving them aid and comfort. No person shall be convicted of treason, unless on the testimony of two witnesses to the same overt act, or on confession in open court". Article 3, Section 3, Clause 2 provides "The Congress shall have power to declare the punishment of treason, but no attainder of treason shall work corruption of blood, or forfeiture except during the life of the person attainted". It is well settled that Congress can neither extend nor restrict the crime. ${ }^{9}$ When a confession is made out of court, it is not itself sufficient to convict even though the confession is proved by two witnesses. ${ }^{10}$ Words, oral, written or printed, however treasonable, seditious or criminal in themselves do not constitute an overt act of treason within the definition of the crime; but are admissible as evidence of intent, as well as of the act itself, either in finding a bill of indictment or on the trial of it. ${ }^{11}$

But the founders of the Constitution were not omniscient. With all of the genius at their command they did not succeed in making the treason clause usurpation proof. At two different times in our history, Congress has circumvented these elaborate safeguards by a bit of legal legerdemain. By a mere change in nomenclature, Congress has created a new crime called "sedition". No eyewitnesses are necessary and the government does not have to worry about establishing an overt act. In short it is a much more dexterous method of dealing with obnoxious political offenders. But in fairness, it must be said that improvement has been made in our public morality. Men no longer pay the death penalty because they are believed to have a "bad heart".

The press was introduced into England by Henry VII, the first Tudor (I485-I 509), and the opinion prevailed that it was part of the prerogative of the King to govern it. He attempted to do this first by licensing the printer. ${ }^{12}$ This practice of making printing a monopoly based on royal patent continued until $1637 .{ }^{13}$ This first attempt to control the press by licensing the printer having failed, the next step was the licensing of the book. By Star Chamber decree and by Parliamentary Ordinance, by Royal Proclamation and by Common Law, it was next laid down that all books and papers printed by anyone must be submitted to licensers and be registered by the

${ }^{9}$ United States v. Hoxie, I Paine 265 (U. S. C. C. Vt. I808).

${ }^{20}$ United States v. Fries, 3 Dall. 514 (U. S. I799) ; United States v. Grenier, 4 Phila. 396 ( Pa. I86I).

${ }^{11}$ Laze of Treason, 5 Blatch. (U. S. I869) 549 (Appendix).

12 Scarlett's argument in LoRd Abinger, MeMoIr of James I, 297.

${ }^{13}$ Wickwar, The Struggle for the Freedom of the Press (19a8) i4. 
Stationer's Company (the beneficiaries of royal patent) before being published. Largely through the criticisms of Milton ${ }^{14}$ and Blount ${ }^{15}$ the King's licenser became so unpopular that Parliament in 1695 failed to renew the Licensing Act ${ }^{16}$ in its original form, and the session closed before a Select Committee had time to report a less objectionable measure.

The next device to abridge intellectual freedom began in I7II with the levying of the so-called taxes on knozeledge. George Jacob Holyoake describes the situation as follows: "Yet every newspaper proprietor was formerly treated as a blasphemer and a writer of sedition and compelled to give substantial securities against the exercise of his infamous tendencies; every paper maker was regarded as a thief. Every reader with an unstamped paper was liable to a fine of twenty pounds." 17 Holyoake violated these tax laws until the penalties amounted to $\$ 3,000,000$.

Although the failure of Parliament in I695 to renew the Licensing Act did away with the official licenser, the theory of censorship continued and it was under these conditions that Blackstone almost a century later formulated his conception of freedom of speech and press: "The liberty of the press is indeed essential to the nature of a free state: but this consists in laying no previous restraints upon publications, and not in the freedom from censure for criminal matter when published. . . . To subject the press to the restrictive power of a licenser, as was formerly done, both before and since the Revolution [of I688-89] is to subject all freedom of sentiment to the prejudices of one man, and make him the arbitrary and infallible judge of all controverted points in learning, religion, and government. But to punish (as the law does at present) any dangerous or offensive writings, which, when published, shall on a fair and impartial trial be adjudged of a pernicious tendency, is necessary for the preservation of peace and good order of government and religion, the only solid foundations of civil liberty." 18

It should be noted that the change that prohibited previous restraint in favor of ex post facto censorship did not enlarge intellectual liberty. The Blackstonian conception held the field for a number of years. The great Whig historian, Hallam, in 1827 parroted the Blackstonian doctrine that "Liberty of the press consists, in a strict sense, merely in an exemption from the superintendence of a licenser." 19 It was followed by early American judges in contempt proceedings and prosecutions for libel, ${ }^{20}$ and the adher-

It AREOPAGiTiCa (I644).

2s $A$ Just Vindication of Learning and the Liberty of the Press, Blount, Miscellaneous WORKS (I695).

${ }^{10}$ WICKWAR, loc. cit. supra note I3.

17 Collet, History of TAXes ON KNOWledge (1899) 47; Patterson, Liberty of the Press 57.

${ }_{18} 4$ BL. Cons. (4th ed. I770) *I5I.

${ }^{10} 3$ Hallam, Constiturional History (1823) xv.

- McKean, J., in Respublica v. Oswald, I Dall. 343 ( $\mathrm{Pa}$. r788) ; Wm. Cobbett's trial, Wharton, State Truals (I849) 322; Yeates, J., in Respublica v. Dennie, 4 Yeates 267 (Pa. I805); Parker, J., in Commonwealth v. Blanding, 3 Pick. 304 (Mass. 1825). 
ents of this doctrine maintained that the First Amendment had enacted Blackstone's definition. As late as Igo7 Justice Holmes, speaking for the Court in Patterson v. Colorado ${ }^{21}$ said "The main purpose of such constitutional provisions is 'to prevent all such previous restraints upon publications as had been practiced by other governments', and they do not prevent the subsequent punishment of such as may be deemed contrary to the public welfare. The preliminary freedom extends as well to the false as to the true; the subsequent punishment may extend as well to the true as to the false." Justice Holmes repudiated this contention in the Schenck case, ${ }^{22}$ but his words have had some influence, particularly in Espionage Act cases. ${ }^{23}$

Let us consider the criticisms of the Blackstonian theory. Professor Chafee has shown that under this doctrine "the line where legitimate suppression begins is fixed chronologically at the time of publication. The government cannot interfere by a censorship or an injunction before the words are spoken or printed, but can punish them as much as it pleases after publication, no matter how harmless or essential to the public welfare the discussion may be." 24 Such a doctrine gives no protection to political criticism because it is utterly devoid of any intrinsic test by means of which the limits of permissible utterance may be determined. Its application is governed almost entirely by the predilections and prejudices of the judge in the case. The judge has a choice of several alternatives, the selection of any one of which may unduly curb freedom of speech and press.

\section{I}

The court may adopt the "use-abuse" theory and fulminate about "liberty" and "license". This utilization of "word-magic" will lead the judge to any conclusion that he wishes to reach. He may lead off with the eloquent statement, "The liberty protected is not the right to perpetrate acts of licentiousness", ${ }^{25}$ but whether aware of it or not, he has not even started on an analysis of his case. A classic illustration of the employment of this legal folderol is in Lord Kenyon's statement made during the French Revolution: "The liberty of the press is dear to England. The licentiousness of the press is odious to England. The liberty of it can never be so well protected as by beating down the licentiousness." ${ }^{26}$ The words "liberty" and "license" and "use" and "abuse" do not contain within themselves any standard of guilt or innocence and if a judge insists on utilizing them in charging a jury, it is submitted that both the jury and the victimized defendant, as far as content

205 U. S. 454 at 462,27 Sup. Ct. 556 at 558 (1907).

Supra note I.

$\approx$ Masses Publishing Co. v. Patten, 246 Fed. 24 (C. C. A. 2d, I9I7).

${ }^{24}$ Chafee, Freedom OF SPEech (Ig20)*8.

2 Hammersly, J., in State v. Marx, 78 Conn. 18, 28, 60 Atl. 690, 694 (1905).

${ }^{2} 2$ STEPHEN, History OF CRIMINAL LAW (1883) $348 \mathrm{n}$. 
is concerned, have the same idea, as did Governor Altgeld of William Jennings Bryan's "Cross of Gold" speech. ${ }^{27}$

\section{II}

Further, the Blackstonian theory permits the court to punish the author of a statement for its bad tendency. Thomas Jefferson realized the danger of such a theory when he declared: "To suffer the civil magistrate to intrude his power into the field of opinion, and to restrain the profession or propagation of principles on supposition of their ill tendency, is a dangerous fallacy, which at once destroys all religious liberty, because he being of course judge of that tendency will make his opinions the rule of judgment, and approve or condemn the sentiments of others only as they shall square with or differ from his own." 28 The dread of certain opinions, because of their bad tendency, has been the copious source of most of the religious wars and persecutions that have disgraced the history of western Europe and America.

In the field of political and economic ideas, under the bad tendency doctrine, it is easy for the administration in power in war time to brand the views of the opposition as criminal. No doctrine has ever been devised that places a more irresponsible power in the courts to punish political and economic heresy. In order that its danger may be appreciated! fully, we desire to introduce certain pertinent considerations.

(a) No legal doctrine can be evaluated accurately in the abstract. To understand how the bad tendency doctrine operated in the Debs case, it is imperative that we consider the war psychosis that enveloped our officialdom during the World War. It has been truly said that "war hath no fury like the non-combatant". The first step was for the government to set up a propaganda organization. In order to be certain that there should be a conscription of minds, "The Committee on Public Information", more accurately characterized as the "Creel Psychological Laboratory for the Preparation of War Truth", was created to poison the sources of public information. As an anonymous English writer has pointed out, ${ }^{29}$ Creel and his associates were master pragmatists. They were firm believers in the dogma that "truth is what works". "They produced out of the same raw material the separate truths which war requires for the home consumer, the Ally, the neutral and the enemy. It became merely a question of preparing and applying the requisite alloy." No historical scholar today believes the mass of war myths deliberately created and circularized by our government, and yet, strange to relate the Attorney General of the United States, Mr. Gregory, defended the

${ }^{27}$ Darrow, The Story of My Life (1932) 89.

${ }^{23}$ Quoted in 2 Watson, The Constitution (19io) 137 et seq.

${ }^{2}$ Luctan (Headley Bros., Ltd., London, I920) 8. 
Espionage Act on the ground that propaganda was especially dangerous in a country governed by public opinion. ${ }^{30}$

In the second place, war having been declared, a "Psychological Gresham's Law" dominates the government. "Just as in commerce debased coin, if there be enough of it, must drive out the sterling, so in the contest of motives, action which responds to the more primitive feelings and impulses, to first thoughts and established prejudices" 31 often prevails. The extremist is in the saddle. He has been thrilled by the chanting of a hymn of hate. The love of power for the sake of power, has become an obsession. Driven on by curious combination of motives, the legislator introduces an outrageously extreme measure, which not only violates constitutional guarantees but also in effect wages war on the citizen and on the American tradition of tolerance.

And then comes into play a vicious logic in the halls of Congress. The argument is made that this measure, introduced by the extremist, will help win the war. Therefore the Congress must adopt this measure. Any man who is not in favor; any man who desires to compromise, is against winning the war. As part and parcel of the same philosophy, that the government can kill an idea by force and that all men can be made to think alike in wartime, we next introduce what has been called the "now-that-we're-in patriotism". The adherents of this strange doctrine would limit criticism to those only who favor the war. Senator La Follette declared, in one of the greatest speeches that has been delivered in the Senate in this generation, "It is said by many persons for whose opinions I have profound respect and whose motives I know to be sincere that 'we are in this war and must go through to the end'. That is true. But it is not true that we must go through to the end to accomplish an undisclosed purpose, or to reach an unknowm goal'.$^{32}$

(b) It is easy: to comprehend how in this atmosphere courts may fail to distinguish between those who seek to change a law and those who urge disobedience of a law. Vigorous language must be used in either case. In fact, the bad tendency doctrine goes a long way in bridging the gap and making the two synonymous. The patriot may criticise army food, or army barracks or the Y. M. C. A. or the excess profits tax law or the Conscription Act and under the bad tendency doctrine he is caught in the same net as the traitor who seeks an overthrow of our institutions.

(c) Since the bad tendency doctrine contains within itself no test of guilt, the judge in utilizing it is given free rein to read into it his own predilections. If he happens to belong to the school of thought that cannot compre-

${ }^{30}$ Rep. AtT'y Gen. (IgI8) 2I. This idea is criticized by Professor Chafee in Freedons OF SPEECF $x 76$.

su Norman Anget, The Press and the Organization of Society (rg22) 33.

55 CONG. REC. 7885 (I9I7). 
hend the social value of political heresy, it will follow that any vehement criticism of the temporary majority in power will be construed as intentional obstruction of the war program. Norman Angell ${ }^{33}$ has pointed out that "the service that the heretic, political or religious, does is not necessarily to give us the right view; he often perhaps gives us the wrong. What he does by his objections is to compel us to take stock of our own ideas, when otherwise they would remain unexamined, and so to modify them when they are faulty. That service we need in wartime. A democracy will wage war more effectively if public discussion is as free as possible. Experience would seem to show that a democracy will get the best results by a degree of toleration which would allow war aims and peace terms, the justice or injustice of the war, when it ought to stop and on what conditions, all to be freely discussed." It is a far cry from the view of the Continental Congress that we need liberty of the press, that "oppressive officials are shamed or intimidated, into more honorable and just modes of conducting affairs", ${ }^{34}$ and the charge of Judge Van Valkenburgh during the World War that freedom of speech means the "protection of criticism which is made friendly to the government, friendly to the war, friendly to the policies of the government".35 The Czar of Russia, in the heyday of his power, would endorse this brand of freedom of speech.

The danger of the bad tendency doctrine can only be appreciated fully by those who are familiar with the history of political and economic ideas. Majorities are temporary; the heresy of one generation becomes the orthodoxy of the next, hence passing popular ideas should not be privileged. A great champion of freedom of speech has said, "Where all truths are relative and all humans equal before the law no opinion can be too sacred to be laughed to scorn. The right of free speech includes the right to laugh, even at the gods." 38

(d) Since under the bad tendency doctrine, permissible criticism is limited to those who favor the policies of the administration, it follows that truth has nothing to do with the case. The aim is non-interference with the war program. The bad tendency adherents do not recognize the legitimacy of the Alexander Hamilton doctrine that "liberty of the press consists in the right to publish with impunity truth, with good motives, for justifiable ends, though reflecting on government, magistracy, or individuals." 37 While the Espionage Act was pending in the Senate, Senator France of Maryland

${ }^{3}$ Freedont of Discussion in War Time (I9I8) ANN. OF AM. ACAD. OF SCI I95203 .

in I Journals of the Continental Congress (1904) IOS.

3 United States v. Rose Pastor Stokes, BULI. DEPT. OF Justrce, No. 106, p. 14. REv. 89.

${ }^{30}$ Theodore Schroeder, The Psychologic Study of Judicial Opinion (r918) 6 CaLIF. L.

अ As attorney for Croswell, Hamilton expounded the above doctrine which has been repeated many times. Two of the four judges agreed with him. See People v. Croswell, 3 Johns. Cases 337 (N. Y. 1804). 
sought to have inserted the following provision: "Provided, however, that nothing in this act shall be construed as limiting the liberty or impairing the right of any individual to publish or speak what is true with good motives and for justifiable ends." 38 The provision passed the Senate, but at the request of the Attorney General, it was stricken out in conference. The Attorney General said, "Experience teaches that such an amendment would to a large degree nullify the value of the law and turn every trial into an academic debate on insoluble riddles as to what is true." 39 In the great struggle to make the world safe for democracy, our officials forgot the American tradition of tolerance so eloquently expressed by Justice Holmes in the dissent in the Abrams case, "But when men have realized that time has upset many fighting faiths, they may come to believe even more than they believe the very foundations of their own conduct that the ultimate good desired is better reached by free trade in ideas-that the best test of truth is the power of the thought to get itself accepted in the competition of the market, and that truth is the only ground upon which their wishes safely can be carried out." 40

\section{III}

Closely related to the doctrine of bad tendency is what Professor Freund calls the "damning doctrine of inferential intent". ${ }^{41}$ Under the Blackstonian theory, the court is permitted to punish the political heretic who expresses an obnoxious and unpopular creed by utilizing this convenient fiction. On the theory that a man is presumed to intend the consequences of his acts, any citizen who criticises the conduct of a war or vigorously advocates the change of a policy is presumed to intend to weaken the United States Government in the one case or incite disobedience in the other. If this fiction is taken literally, it is obvious that it would wipe out the well-settled and sound distinction between intentional and negligent acts. ${ }^{42}$ The so-called presumption that every man intends the probable consequences of his acts is not a rule of law "further or otherwise than as it is a rule of common sense." 43 In fact there is no such legal presumption. It is merely a pre. sumption of fact which the law sometimes sanctions, or approves or allows a jury to act upon. And the admission that it is an inference of fact and not of law proves that its application depends on varying circumstances. ${ }^{44}$

The "use-abuse", the "bad tendency" and "inferential intent" doctrines give full play to the predilections and prejudices of the judge. Blackstone

${ }^{3 s}$ This was on the Amendment of May, 19I8; see 55 CoNG. REc. 6047 (I9I8).

${ }^{39}$ Id. 6052 .

to Abrams et al. v. United States, 250 U. S. 616, 630, 40 Sup. Ct. I7, 22 (19r9).

"Chafee, Freedom of Speech and Press (I921) 25 NEw REPUBLIC 344.

25ee Jeremiah Smith, Surviving Fictions (r9I8) 27 YALE L. J. 147, 156, 157.

2 STEPHEN, op. cit. supra note 26 , at III.

" Peters, C. J., in State v. Hersom, 90 Me. 273, 275, 38 Atl. 160, 161 (1897). 
believed in witchcraft and as a judge sentenced a "witch" to die. In his Commentaries he says, "To deny the possibility, nay, actual existence, of witchcraft and sorcery, is at once flatly to contradict the revealed word of God, in various passages of both the old and new testament: and the thing itself is a truth to which every nation in the world hath in its turn borne testimony, by either examples seemingly well attested, or prohibitory laws, which at least suppose the possibility of a commerce with evil spirits." 45 Under the above doctrines, a heretic of Blackstone's day, who was affiliated with an Anti-Witchcraft Society, would have been imprisoned as striking perilously near the foundations of church and state.

The Schenck case is significant because it repudiates the outworn doctrines that were used for centuries in England to send political offenders to the Tower. Justice Holmes, speaking for a unanimous Court, breaks with the past and does not rely on the principles of liberty and license, indirect causation, constructive intent, remote bad tendency, unpopular motive or bad heart. The test of guilt is whether the words used are used in such circumstances and are of such a nature as to create a clear and present danger that they will bring about the substantive evils that Congress has a right to prevent. In the words of our greatest authority on freedom of speech, "This test draws the boundary line very close to the test of incitement at common law and clearly makes the punishment of words for their remote bad tendency impossible." 40 In short, the Schenck doctrine comes close to limiting criminal liability to words which directly incite acts in violation of law. It approaches the common law doctrine of criminal attempt: (I) the attempt must be a step toward a crime, (2) there must be an apparent adaptation of means to result, and (3) dangerous proximity to success; an objective test. ${ }^{47}$

While the Schenck case represents the high-water mark of liberalism in freedom of speech cases, an analysis of that decision will bring to light four important considerations.

(I) It should be noted that the Supreme Court did not accept the Jeffersonian idea that "it is time enough for the rightful purpose of civil government for its officers to interfere when principles break into overt acts against peace and order." 48 In the Utah polygamy case the Supreme Court of the United States endorsed emphatically this Jeffersonian doctrine and said that it represented "the true distinction between what properly belongs

${ }^{25} 4 \mathrm{BI}$. CoMm. *6o.

${ }^{48} \mathrm{CHAFEE}$, op. cit. supra note 24 , at 89.

"Beale, Criminal Attempts (Ig03) I6 HaRv. L. Rev. 49 I.

¿s The Language used is from Jefferson's Act of Toleration quoted in 2 WATson op. cit. supra note 28, at 1379. A similar view was expressed by Mr. Erskine in the famous trial of Thomas Paine "that opinion is free and that conduct alone is amenable to law". I ERSKINE SPEECHES (1870) 313 . 
to the Church and what to the State."49 But in the freedom of speech case the court has never gone this far. The Schenck doctrine declares that the government may interfere when there is a clear and present danger that the words used will bring about the overt act that is prohibited by law. ${ }^{50}$

(2) It should also be noted that the Supreme Court in the Schenck case did not accept without qualification the Montesquieu doctrine that "words do not constitute an overt act. Everything is confounded if words are construed into capital crime; instead of considering them only as a mark (evidence) of that crime." 51 Prior to the American revolution this controversy raged in England. Lord Coke was among those who maintained that mere words should not be considered as overt acts. "Bare words may make an heretic, but not a traitor, without an overt act." 52 Our Constitution was designed to settle that controversy by the insertion of the treason clause. If the courts will not construe the First Amendment in the light of the treason clause, then Congress by a mere change in nomenclature can punish bare words and frustrate the intent of the framers of our fundamental law. Given the proper setting under the Schenck doctrine, mere words might create the clear and present danger.

(3) The Schenck doctrine establishes liability only when there is a clear and present danger that the words used will bring about the "substantive evils" that Congress has a right to prevent. What are the limits on Congress in denominating substantive evils? The cases to date do not give a definite answer to that query. The constitutionality of the Espionage Act was decided in the Schenck case without any extended reasoning indicating where the line would be drawn between valid and invalid legislation. Later cases have really confined the question of constitutionality to the limitations on judicial legislation (by the process of construing) rather than upon the limitations on legislation by Congress. ${ }^{53}$

Ernest Freund has pointed out that "the vagueness of definition that characterizes the Espionage Act finds no parallel in modern foreign legislation." 54 The Supreme Court of the United States has put its seal of condemnation on this practice, in the following words: "It would certainly be dangerous if the legislature could set a net large enough to catch all possible offenders, and leave it to the courts to step inside and say who could be rightfully detained, and who should be set at large. This would, to some extent, substitute the judicial for the legislative department of the government." 55

\footnotetext{
Reynolds v. United States, 98 U. S. I45, I63 ( 1878 ).

6o Theodore Schroeder has been the great champion of the Jeffersonian doctrine in freedom of speech cases; see Concerning the Meaning of Freedom of Speech and Press (1909) 68 CENT. L. J. 227 ; FrEE SPEECH FOR RADICALS (I916) $37,45$.

a I Montesouieu, The SpIRIt OF the Laws (Nugent's tr. I823) I93.

${ }^{2}$ Care aND Nelson, ENGLISH LiberTies (4th ed. 1719) 82.

See Note (1920) 14 IIL. L. REv. 601, 605.

Freund, The Debs Case and Freedom of Speech (1919) Ig NEw Republic 13, I4.

$\approx$ United States v. Reese, 92 U. S. 214, 221 (1875).
} 
(4) Finally, although the Schenck case is a great improvement over the bad tendency and bad intent doctrines, it should not be assumed that the case lays down an absolutely definite test of criminal liability. There is still some opportunity for judges and juries to give play to their economic and political biases. Given the mental predisposition, induced by popular panic, together with intense emotions some judges and some juries will be able to see a "clear and present danger" where none in fact exists.

Many of the federal judges were victims of the war psychosis and their charges to juries bore all of the earmarks of impassioned stump speeches. One federal district judge in charging a federal grand jury, after calling by name Senators Stone, Harwick, Gronna, Vardman, and La Follette said, "If I had a wish, I would wish that you men had jurisdiction to return bills of indictment against these men. They ought to be tried, promptly and fairly, and I believe this court could administer the law fairly; but I have a conviction as strong: as life, that this country should stand them up against an adobe wall tomorrow and give them what they deserve. If any man deserves death it is a traitor. I wish that I could pay for the ammunition. I would like to attend the execution and if $I$ were in the firing squad I would not want to be the marksman who had the blank shell." 58

And then there was Judge Kenesaw Mountain Landis, who in an address before the American Protective League in Minneapolis displayed none of the characteristics of the judicial type of mind. He declared, "What we need is a new definition of treason. Then we can use the side of a barn for those who would destroy our government." 57 He would make political heresy a crime, in the vain hope that all men could be made to think alike in war-time. It was Judge Landis who sentenced Victor Berger and the Socialist party. ${ }^{58}$

The liberalism of the Schenck doctrine would vanish in the hands of judges and juries of this stamp. Even in the case where the judge maintains a judicial attitude of mind it has been suggested that ${ }^{50}$ the "clear and present danger" test would not necessarily be the same as the "dangerous proximity to success" test in the law of criminal attempt. The latter has acquired a meaning in the case of specific offenses by a process of inclusion and exclusion as the result of a series of cases dealing with attempts to commit a particular crime. The want of such blocking out by judicial decision in the case of political offenses makes the test somewhat vague.

To recapitulate, prior to the Schenck case, it was considered orthodox. for the courts to utilize the damning doctrine of inferential intent and the equally pernicious doctrine of remote bad tendency. Both of these doc-

${ }^{c}$ Hon. Waller T. Burns, U. S. District Court sitting in Houston, Texas, October I, 1917. See 55 CoNG. REc. 7878 (I9I7).

St. Louis Globe Democrat, Feb. 2, 1920.

w For similar expressions of unreasoning passion and intolerance, see the remarks of Wigmore, The Abrains Case (Ig20) I4 ILI. L. REv. 539, 552.

${ }^{{ }^{2}}$ Note (Ig20) 33 HARv. L. Rev. 442. 
trines bore a Jeffriesian smack and had played a notorious role in persecuting political minorities in England and America. The Schenck case with all of its limitations, established a much more liberal test of guilt and outlawed both of the above vicious doctrines. Even under the new test, the court was able to "get its man". Justice Holmes spoke for a unanimous Court, the decision being rendered on March 3, I9I9. The Court realized that it was committing itself to a new doctrine. No authority or precedent was cited for the "clear and present danger" test. Editors of liberal, magazines and newspapers commented favorably upon the change. And strange to relate, all of the while that this new body of law was being formulated, the Debs case was pending. One week later, on March IO, I9I9, Justice Holmes again spoke for a unanimous court, but in order to convict Mr. Debs it was necessary for the court to abandon the Schenck "clear and present danger" test, and Justice Holmes proceeded to do so. ${ }^{60}$

In the later case of Gitlow v. State of New York, ${ }^{61}$ another freedom of speech case, Justice Holmes dissented and attempted to show his consistency by reaffirming the clear and present danger test. He said, "It is true that in my opinion this criterion was departed from in Abrams v. United States, ${ }^{62}$ but the convictions that I expressed in that case [in the dissent] are too deep for it to be possible for me as yet to believe that it and Schaefer $v$. United States ${ }^{63}$ have settled the law." But the venerable Justice says ne'er a word about his own departure from his own test in the Debs case.

Debs was convicted because of a speech that he delivered at Canton, Ohio, June 16,1918 , at a Socialist picnic. On the basis of an examination of the Debs speech and the Debs decision. we shall attempt to show (I) that the Debs decision was a departure from the Schenck doctrine, (2) that it would have been impossible to have convicted Debs if the court had follower the "clear and present danger" test, and ( 3 ) in conclusion we shall introduce some considerations as to the reasons for this most peculiar tergiversation in the history of the Supreme Court.

Was the Debs decision a departure from the Schenck doctrine?

(I) In the Debs case the "clear and present danger" test was not mentioned although the case was decided just one week after the Schenck case and the court realized that it was taking an advanced position in the Schenck case. (2) In the Debs case Justice Holmes would not go behind the verdict which was found in Judge Westenhaver's court. The Debs trial was held before the Schenck case was decided. It is admitted that Judge Westenhaver did not employ the "clear and present" danger test. In his charge to the jury he said, "In deciding what the defendant's intention was, permit me

\footnotetext{
${ }^{\infty}$ CEAFEe, op. cit. supra note 24 , at 90 , $9 \mathrm{I}$.

a 268 U. S. 652, 673, 45 Sup. Ct. 625, 632 (I924).

-2 Supra note 40 .

${ }_{25} 2$ I U. S. 466, 40 Sup. Ct. 259 (Ig20).
} 
to suggest to you these questions: Ought he not to have reasonably foreseen that the natural and probable consequences of such words and utterances would or might be to cause insubordination, etc. ?" 64 As Professor Chafee has pointed out, the Supreme Court "allowed Debs to be found guilty because of the natural tendency and reasonably probable effect of his speech, and thus gave a fairly wide scope to the doctrines of indirect causation and constructive intent, so that the defendant could have been and probably was convicted for an exposition of Socialism, merely because the jury thought his speech had a tendency to bring about resistance to the draft." ${ }^{65}$ (3) It is futile for the Supreme Court to formulate a test of liability in freedom of speech cases unless the court is willing to assume the responsibility of determining whether the trial judge's rulings are consistent with the test as formulated.

Would Debs have been convicted if the court had followed the "clear and present danger" test? ${ }^{66}$ The particular count upon which Debs was found guilty was for "obstructing and attempting to obstruct the recruiting service of the United States". ${ }^{87}$ Let us examine the utterances of Debs upon which the conviction was based. According to the Supreme Court's decision "the main theme of the speech was socialism, its growth and ai prophecy of its ultimate success." The speaker made a bitter attack on wart and stated that "the master class has always declared war and the subject class had always fought the battles" and linked the origin and motives of war with the capitalist system. He further approved the conduct of persons convicted of like offenses, saying, for example, that if Rose Pastor Stokes was guilty so was he. (Mrs. Stokes' conviction was later reversed.) It is not claimed that he urged his hearers to resist the draft. He was not speaking to soldiers and there is nothing to show actual obstruction or a direct attempt to interfere with any of the processes of recruiting. ${ }^{68}$ Indeed it is true that he was expressing a view that was obnoxious to the administration in power, but in punishing him the government was relying on the recognition of such a thing as indirect provocation and implied or inferential incitement. Such a doctrine, in the field of political offenses spells arbitrary power.

It is difficult to conceive of a form of obstruction aimed at a compulsory draft that would be punishable under the Schenck doctrine other than open resistance or a direct incitement. Neither was alleged or proved in the Debs case and yet he was convicted because in the language of Justice

* United States v. Debs, Bur.. Depr. of Justice, No. I55 (N. D. Ohio, 1918).

“ CHAFEE, op. cit. supra note 24, at 9r.

${ }^{\infty}$ Prof. Chafee was one of the first to assert that "it is hard to see how he could have been held guilty". FrEEDOM OF SPEECH 90 .

or This is the fourth count, which the Supreme Court sustained.

${ }^{\infty}$ Freund, supra note 54, at I4. 
Holmes the "words used had as their natural tendency and reasonably" probable effect to obstruct the recruiting service". In the Schenck case, Justice Holmes declared that "the most stringent protection of free speech would not protect a man in falsely shouting fire in a theater and causing a panic." "9 Could any adherent of the "clear and present danger" test who has read the Debs speech claim that the same relationship existed between Debs' utterances and the obstruction of the recruiting service as is found in the hypothetical theater case between the cry of "fire" and the ensuing panic? Further, it is submitted that in the theater case, if after the cry of "fire" nothing happened, there would be no liability. The evidence in the Debs case does not disclose that anything happened after and as the result of the utterances. And if the theory of the case is that there was an attempt to obstruct the recruiting service, one will look at the decision in vain to find any objective test to show that there was a dangerous proximity to success. But as soon as we apply the notoriously loose doctrines of indirect causation and constructive intent to offenses of a political character, "we are adrift on a sea of doubt and conjecture. To know what you may do and what you may not do, and how far you may go in criticism, is the first condition of political liberty; to be permitted to agitate at your peril, subject to a jury's guessing at motive, tendency, and possible effect, makes the right of free speech a precarious gift." 70

The Supreme Court in the Debs case revived the old doctrine of constructive crime. The decision is strictly in accord with the idea that dominated American officialdom during the war, an idea which has been aptly designated as the "now-that-we're-in patriotism". Those who held this belief would brook no discussion of war aims and no criticism of governmental policies. In so doing they violated a great Anglo-American tradition.

Had our governmental officials forgotten that Edmund Burke, the Earl of Chatham, Pitt and Fox and Lord Camden had opposed the Revolutionary War and that under the Debs decision, they would have been sent to prison? Did they know that John Bright denounced the Crimean War while that war was being fought and that Lloyd George impeached England's motives in the Boer War after England was in it? Was our governing class ignorant of the fact that this illustrious group of English statesmen could be matched by a galaxy of famous Americans, who believed in the same tradition of free discussion? Let it never be forgotten that Lincoln and Clay and Webster and Sumner opposed the Mexican War while that war" was in progress, and boldly discussed the issues and criticised the policies of the Polk administration.

\footnotetext{
${ }^{69} 249$ U. S. at 52, 39 Sup. Ct. at 249.
}

${ }^{70}$ Freund, supra note 54 , at $\mathrm{I3}$. 
Charles Sumner in a speech at Tremont Temple, Boston, November 5, I846, said, "The Mexican War is an enormity, born of slavery. Base in its object, atrocious in beginning, immoral in all of its influences, vainly prodigal of treasure and life, it is a war of infamy, which must blot the pages of our history." "71 Daniel Webster, in Faneuil Hall on the very next day said, "We are in my opinion in a most unnecessary and therefore a most unjustifiable war." 72 Could it not be argued that these two utterances, by these two eminent statesmen, would have the "incidental effect of discouraging enlistments"?

How many patriots who favored the incarceration of Eugene Debs knew that General George B. McClellan was nominated for President in I864 on a Democratic platform that condemned the Civil War and the policy of the government in conducting it-and this at the very height of our fratricidal strife? Daniel Webster, when a young man well expressed the American tradition of tolerance. Referring to the War of I8I2 he said, "It is the ancient and undoubted prerogative of this people to canvass public measures and the merits of public men. It is a home-bred right-a fireside privilege. . . . This high constitutional privilege I shall defend and exercise within this House, and in all places, in time of war; in time of peace and at all times." 73

Eugene V. Debs, following in the footsteps of these illustrious men, paid the penalty and was branded a criminal. In order that the record may be accurate it should be stated that there was one additional count ${ }^{74}$ against Mr. Debs that could not be raised against the others; he was a Socialist and had even aspired to be President of the United States, being the nominee of this un-American political minority. Who can say that the Supreme Court of the United States locked up Eugene Debs' ideas by locking up Eugene Debs' body?

${ }^{7}$ Quoted in Hearings, Senate Committee Privileges and Elections, 65th Cong. (I9I7), in re Ia Follette Speech 79.

Iz Ibid.

${ }^{7}$ Ann. Cong., I3th Cong., Jan. I4, I814.

74 In the case of Abrams v. United States, supra note 40, at 629, 40 Sup. Ct. at 22, wherein Justice Holmes, by way of dissent, tried to show his consistency in freedom of speech cases, the venerable justice referred to the defendants in that case as "poor and puny anonymities". Eugene Debs was not of that stripe. But even as leader of the Socialist Party it is submitted that if the Schenck test had been used the Supreme Court would not have been able "to squeeze enough" from his speech "to turn the color of legal litmus paper". 